\title{
Effects of fencing on vegetation and soil restoration in a degraded alkaline grassland in northeast China
}

\author{
Qiang $\mathrm{LI}^{1,2}$, DaoWei ZHOU ${ }^{1 *}$, YingHua $\mathrm{JIN}^{3}$, MinLing WANG ${ }^{1}$, YanTao SONG ${ }^{1}$, GuangDi $\mathrm{LI}^{4}$ \\ ${ }^{1}$ Northeast Institute of Geography and Agroecology, Chinese Academy of Sciences, Changchun 130102, China; \\ ${ }^{2}$ University of Chinese Academy of Sciences, Beijing 100049, China; \\ ${ }^{3}$ School of Geography Science, Northeast Normal University, Changchun 130012, China; \\ ${ }^{4}$ Graham Centre for Agricultural Innovation, New South Wales Department of Primary Industries and Charles Sturt University, Wagga, \\ NSW 2650, Australia
}

\begin{abstract}
In order to restore a degraded alkaline grassland, the local government implemented a large restoration project using fences in Changling county, Jilin province, China, in 2000. Grazing was excluded from the protected area, whereas the grazed area was continuously grazed at 8.5 dry sheep equivalent (DSE)/hm ${ }^{2}$. In the current research, soil and plant samples were taken from grazed and fenced areas to examine changes in vegetation and soil properties in 2005, 2006 and 2008. Results showed that vegetation characteristics and soil properties improved significantly in the fenced area compared with the grazed area. In the protected area the vegetation cover, height and above- and belowground biomass increased significantly. Soil $\mathrm{pH}$, electrical conductivity and bulk density decreased significantly, but soil organic carbon and total nitrogen concentration increased greatly in the protected area. By comparing the vegetation and soil characteristics with pre-degraded grassland, we found that vegetation can recover 6 years after fencing, and soil pH can be restored 8 years after fencing. However, the restoration of soil organic carbon, total nitrogen and total phosphorus concentrations needed 16,30 and 19 years, respectively. It is recommended that the stocking rate should be reduced to $1 / 3$ of the current carrying capacity, or that a grazing regime of 1-year of grazing followed by a 2-year rest is adopted to sustain the current status of vegetation and soil resources. However, if $\mathrm{N}$ fertilizer is applied, the rest period could be shortened, depending on the rate of application.
\end{abstract}

Keywords: vegetation and soil restoration; fencing; grazing; alkaline soil; semi arid region; grassland degradation

Citation: Qiang LI, DaoWei ZHOU, YingHua JIN, MinLing WANG, YanTao SONG, GuangDi LI. 2014. Effect of fencing on vegetation and soil restoration in a degraded alkaline grassland in northeast China. Journal of Arid Land, 6(4): 478-487. doi: 10.1007/s40333-013-0207-6

Currently, degraded grassland is widespread throughout the world, and grassland restoration has become a focus for ecologists (van der Merwe and Kellner, 1999; Snyman, 2003; Gonzales and Clements, 2010). Many factors can contribute to grassland degradation, including natural factors such as a long-term drought, wind erosion and sand storms (Schlesinger et al., 1990), and human interferences such as overgrazing (Manzano and Návar, 2000), land use change (Zhao et al., 2005) and mining (Wang et al., 2007).

It is deemed that overgrazing is the primary cause of grassland degradation (Fleischner, 1994; Mainguet 1994; Daily, 1995). Overgrazing has two major im- pacts on grasslands. First, the livestock grazing reduces vegetation height and changes species composition and cover of grassland communities ( $\mathrm{Su}$ et al., 2005). Second, the trampling of livestock can cause serious damage to vegetation and soil during the process of grazing. Livestock trampling destroys the ground protection layer, including plant residues and litter on the soil surface (Taylor et al., 1993; Hofstede, 1995), and compacts soil and reduces soil water penetrability, hence increasing the risk of runoff and causing loss of soil nutrients (Dak and Gifford, 1980). Numerous studies indicate that overgrazing can result in dramatic changes in vegetation and modifications in

*Corresponding author: DaoWei ZHOU (E-mail: zhoudaowei@neigae.ac.cn)

Received 2013-06-13, revised 2013-08-20, accepted 2013-09-29

(c) Xinjiang Institute of Ecology and Geography, Chinese Academy of Sciences, Science Press and Springer-Verlag Berlin Heidelberg 2014 
nutrient cycling in grasslands (Bauer et al., 1987; Dormaar et al., 1994; Lavado et al., 1996).

In recent years, reducing grazing pressure by fencing has been encouraged as an effective way to restore degraded grassland, including the restoration of degraded vegetation and improvement of soil properties in different grassland ecosystems (Pei et al., 2008; Wu et al., 2009; Shang et al., 2013). Previous studies indicate that the restoration of degraded ecosystems depended on climatic conditions, disturbance history, soil texture and propagule resources (Holmgren and Scheffer 2001; Suding et al., 2004; Wang et al., 2013), and the restoration rates of vegetation and soil differ as vegetation generally restores more quickly than soil (Pywell et al., 2002). Therefore, the benefit of fencing may vary in different grasslands and among ecosystem components, such as plants and soil.

Songnen grassland is dominated by Leymus chinensis Tzvel. Most of the area of Songnen Plain is located in a basin surrounded by mountains, and it thus has very poor drainage. The accumulation of solutes induces primarily alkaline soil processes, with $\mathrm{Na}_{2} \mathrm{CO}_{3}$ and $\mathrm{NaHCO}_{3}$ being the major sources for soil alkalinity. High $\mathrm{pH}$ and electrical conductivity are highlighted characteristics for alkaline soil, and these are the principal limiting factors for vegetation establishment in this area (Gao et al., 1996; Jiang et al., 2010). In the last few decades, most of the vegetated area in the Songnen grassland has been degraded severely due to overgrazing (Zhang, 1994). The vegetation degradation and soil erosion exacerbated the alkalinity levels in the surface soil, resulting in a severe secondary alkalinization process. The grassland degradation has restricted the local economy and development of society. Since 2000, with financial support from the government, a large grassland restoration project has been implemented. Large areas of degraded grasslands were protected from grazing by fencing in order to restore ground cover and forage production to the pre-degradation levels of 1983 . However, there is limited information of restoration processes and duration. Therefore, the objective of this study is to understand the mechanisms of restoring vegetation and soil properties and to provide guidelines for farmers to manage severely degraded grasslands of the Songnen Plain in northern China.

\section{Materials and methods}

\subsection{Study area}

The study area is located in Changling county, Jilin province, China $\left(44^{\circ} 15^{\prime} \mathrm{N}, 123^{\circ} 34^{\prime} \mathrm{E}\right)$. The climate in this region is semi-arid. Average annual precipitation from 2000-2008 was 364 mm, about $80 \%$ of which falling between July and September. The annual mean temperature was $4.9^{\circ} \mathrm{C}$. The specific temperature and precipitation information during our experiment years (2005, 2006 and 2008) are shown in Fig. 1. The soil type is meadow solonchaks, according to the FAO/UNESCO taxonomy, with 23\% sand, 37\% silt, and $40 \%$ clay. Soil pH ranges from $8.5-9.5$ and soil organic matter content ranges from $20-25 \mathrm{~g} / \mathrm{kg}$ in the surface layer. L. chinensis has absolute dominance in the local mature vegetation.

\subsection{Sampling and measurements}

In mid-September 2005, two plots of $300-\mathrm{hm}^{2}$ meadow were selected from fenced and freely grazed areas for this paired paddock comparison study. The fenced area has been excluded from grazing since 2000 , but it was subjected to 15 years of extensive livestock grazing from 1985-2000 and was seriously degraded. As a comparison, the outside area was continuously grazed by sheep and cattle at 8.5 dry sheep equivalent (DSE)/hm². The baselines for vegetation and soil in 1983 (pre-degradation) and 2000 (before fencing) are given in Table 1, based on historical survey data.

Two sampling stripes $(100 \mathrm{~m} \times 50 \mathrm{~m})$ were selected randomly inside and outside of the fenced areas. Ten quadrats $(1 \mathrm{~m} \times 1 \mathrm{~m})$ were selected as replicates at 10 -m intervals along the $100-\mathrm{m}$ sampling stripes. In each quadrat, the vegetation height was determined by measuring the vertical height of the tallest parts of the plants, the vegetation cover was estimated, and the number of individuals in each species was counted. All live, aboveground plant materials were clipped at the soil surface for aboveground biomass. Within each quadrat, three soil samples were collected using a soil auger with a $10-\mathrm{cm}$ diameter at depths of $0-10$ and 10-20 cm. These samples were combined into one for each depth. Roots were washed free from the soil. All above- and belowground biomass was dried at $70^{\circ} \mathrm{C}$ 
for $48 \mathrm{~h}$ to determine the dry weight. Within each quadrat, three soil samples were taken randomly using a 5-cm diameter soil auger at the depths of $0-10$ and 10-20 cm, and then combined into one sample per depth for soil analysis. Soil bulk density at the depths of $0-10$ and $10-20 \mathrm{~cm}$ was determined from five replicates by using the core method in each quadrat (Klute, 1986). The same sampling process was conducted in mid-September of 2005, 2006 and 2008.
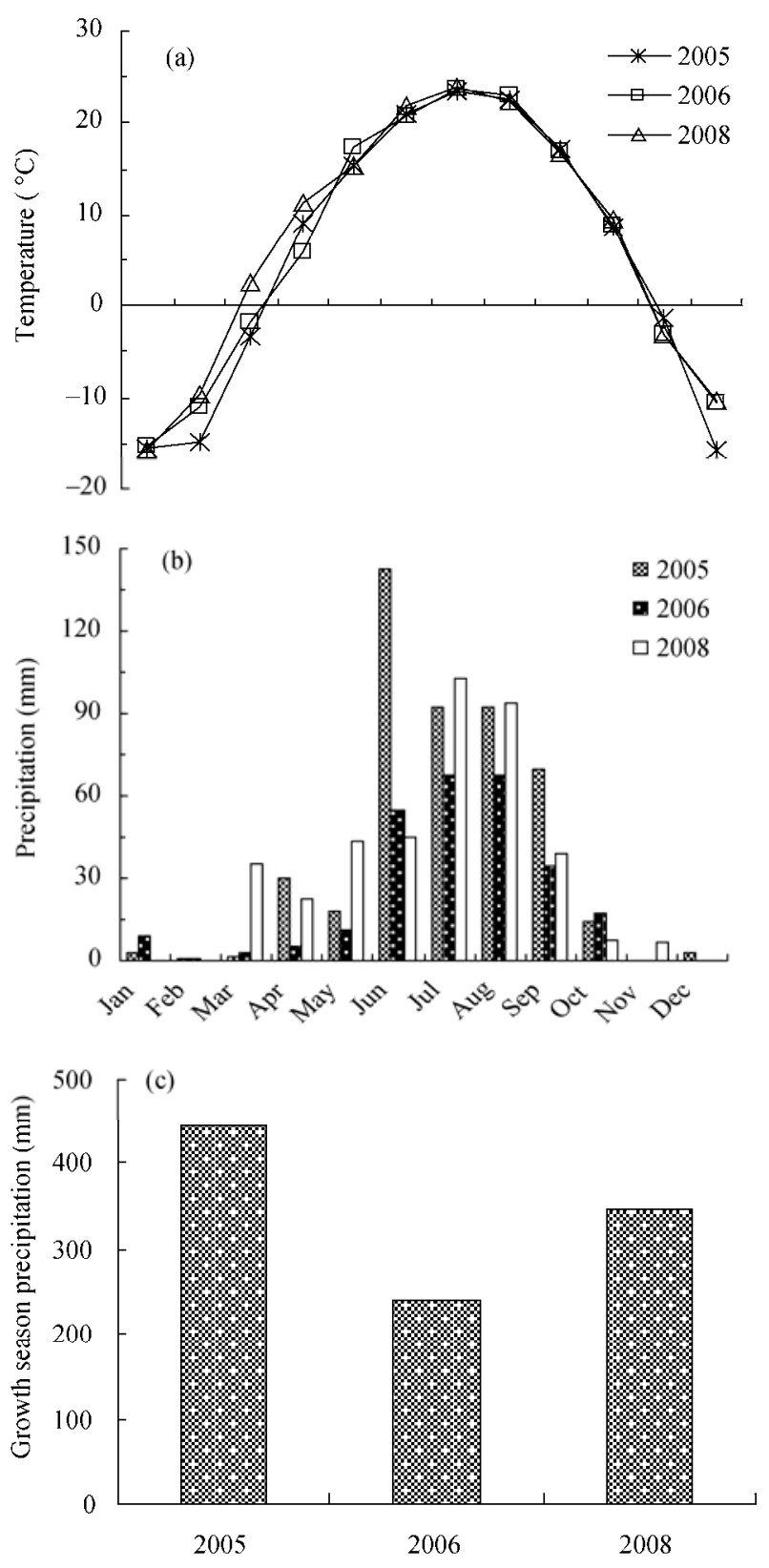

Fig. 1 The monthly temperature (a), monthly precipitation (b) and growth season precipitation (c) in 2005, 2006 and 2008; Growing season lasts from April to September.
Table 1 Vegetation and soil characteristics $(0-10 \mathrm{~cm})$ in the study meadow in 1983 (pre-degradation) and 2000 (before fencing)

\begin{tabular}{llcc}
\hline & Item & 1983 & 2000 \\
\hline \multirow{4}{*}{ Vegetation } & Cover $(\%)$ & 85 & 37 \\
& Height $(\mathrm{cm})$ & 58 & 32 \\
& Plant density (individuals $\left./ \mathrm{m}^{2}\right)$ & \multicolumn{1}{c}{678} & 684 \\
& Above-ground biomass $\left(\mathrm{g} / \mathrm{m}^{2}\right)$ & 359.50 & 192.20 \\
& Bulk density $\left(\mathrm{g} / \mathrm{cm}^{3}\right)$ & 1.34 & 1.47 \\
& $\mathrm{pH}$ & 8.72 & 9.42 \\
Soil & Soil organic carbon $(\mathrm{g} / \mathrm{kg})$ & 12.57 & 6.44 \\
& Total nitrogen $(\mathrm{g} / \mathrm{kg})$ & 1.24 & 0.79 \\
& Total phosphorus $(\mathrm{g} / \mathrm{kg})$ & 0.32 & 0.20 \\
\hline
\end{tabular}

\subsection{Soil analysis}

The soil samples were air-dried and sieved to pass a 2-mm mesh. Then subsamples were ground to pass through a 0.25-mm sieve for analysis of soil organic carbon $\left(\mathrm{C}_{\text {org }}\right)$ using the $\mathrm{K}_{2} \mathrm{Cr}_{2} \mathrm{O}_{7}$ method (Page, 1982), total soil nitrogen $\left(\mathrm{N}_{\text {tot }}\right)$ using the Kjeldahl method (Sparks et al., 1996), and total soil phosphorus $\left(\mathrm{P}_{\mathrm{tot}}\right)$ using a spectrophotometer after $\mathrm{NaOH}$ digestion (ISSCAS, 1978). Soil $\mathrm{pH}$ and electrical conductivity (EC) were determined using a PHS-3C pH meter and a DDS-307 EC meter (Shanghai, China) in a 1:5 soil-water solution.

\subsection{Data analysis}

We used the Richness index $(R)$, Shannon-Wiener diversity index $(H)$ and Evenness index $(E)$ to characterize the community structure characteristics (Wu et al., 2009).

Richness index $(R): R=S$,

Shannon-Wiener diversity index $(H)$ :

$$
H=-\sum_{i=1}^{s} P_{i} \ln P_{i},
$$

Evenness index $(E): E=H / \ln S$.

Where $S$ is the number of species in the community, and $P_{i}$ is the density proportion of $i$ species.

The statistical comparisons of means between fenced and grazed areas were conducted using independent sample $t$-tests. The least significance difference (LSD) was provided to compare the differences in vegetation and soil properties among years. A one-sample $t$-test was performed to determine the effectiveness of fencing on restoring vegetation and soil based on background data in 1983 and measurements in 2000. Pearson's correlation coefficients were used 
to evaluate relationships between the above- and belowground biomass and soil properties. Curve estimation regression was used to predict the time needed for the restoration of soil organic carbon and total soil $\mathrm{N}$ concentrations. Significant differences for all statistical tests were evaluated at $P=0.05$. All data analyses were conducted with SPSS16.0 software (Chicago, IL, USA).

\section{Results}

\subsection{Community composition and structure}

In total, there were 26 species found in fenced and grazed areas during our sampling process in 2005, 2006 and 2008, with 14 species common in fenced and grazed areas, 6 species present only in fenced area, and 6 species only found in the grazed area. The species numbers were lowest in 2006 in both fenced and grazed areas. It was noted that the number of annual grass species present in the fenced area decreased from 4 to 0 between 2005 and 2008. The aboveground biomass of annual species decreased in both fenced and grazed areas, but the aboveground biomass and proportion of $L$. chinensis increased continuously in the fenced area (Table 2).

There was no significant change in species richness between fenced and grazed areas (Fig. 2a). However, species diversity and evenness decreased significantly in the fenced meadow communities $(P<0.05$; Figs. $2 b$ and c). The species diversity and evenness were lower in the fenced communities compared with the grazed communities in $2008(P<0.05$; Figs. 2a and c). In the

Table 2 The mean aboveground biomass $\left(\mathrm{g} / \mathrm{m}^{2}\right)$ of species present in surveyed quadrats in 2005,2006 and 2008

\begin{tabular}{|c|c|c|c|c|c|c|c|}
\hline \multirow{2}{*}{ Species } & \multirow{2}{*}{ Life type } & \multicolumn{2}{|c|}{2005} & \multicolumn{2}{|c|}{2006} & \multicolumn{2}{|c|}{2008} \\
\hline & & Fenced & Grazed & Fenced & Grazed & Fenced & Grazed \\
\hline Leymus chinensis & PG & 134.70 & 18.06 & 283.42 & 87.02 & 360.88 & 35.01 \\
\hline Phragmites australis & PG & 59.88 & 0.30 & - & - & 6.68 & 0.50 \\
\hline Calamagrostis epigejos & PG & 0.64 & - & 11.06 & - & - & - \\
\hline Saussurea runcinata & $\mathrm{PF}$ & 6.74 & - & - & - & - & - \\
\hline Saussurea glomerata & $\mathrm{PF}$ & 0.20 & - & 0.15 & - & 0.01 & 0.11 \\
\hline Cynanchum chinense & $\mathrm{PF}$ & 0.40 & 0.08 & 2.40 & - & 0.22 & 0.01 \\
\hline Sonchus brachyotus & $\mathrm{PF}$ & 2.10 & 0.06 & - & - & 0.21 & 0.12 \\
\hline Brachyactis ciliata & $\mathrm{PF}$ & - & 0.26 & - & - & - & - \\
\hline Potentilla anserine & $\mathrm{PF}$ & - & 0.02 & - & - & - & - \\
\hline Taraxacum asiaticum & $\mathrm{PF}$ & - & 0.24 & - & 0.11 & - & 0.18 \\
\hline Ixeris chinensis & $\mathrm{PF}$ & - & - & - & - & - & 0.03 \\
\hline Plantago asiatica & $\mathrm{PF}$ & - & - & - & 0.07 & - & - \\
\hline Iris lactea & $\mathrm{PF}$ & - & - & 13.63 & - & 0.61 & - \\
\hline Polygonum aviculare & $\mathrm{PF}$ & - & 0.68 & - & - & 0.16 & - \\
\hline Digitaria sanguinalis & $\mathrm{AG}$ & 0.46 & - & - & - & - & - \\
\hline Echinochloa crusgalli & $\mathrm{AG}$ & 6.60 & 25.24 & - & 0.08 & - & 0.04 \\
\hline Chloris virgata & $\mathrm{AG}$ & 35.10 & 28.60 & 0.05 & 3.01 & - & 0.50 \\
\hline Setaria viridis & $\mathrm{AG}$ & 0.78 & 1.36 & - & - & - & - \\
\hline Atriplex patens & $\mathrm{AF}$ & - & 0.14 & - & - & - & - \\
\hline Polygonum sibiricum & $\mathrm{AF}$ & - & - & 0.31 & - & - & - \\
\hline Artemisia anethoides & $\mathrm{AF}$ & 1.98 & - & 1.80 & - & - & - \\
\hline Artemisia scoparia & $\mathrm{AF}$ & - & - & 0.10 & 0.18 & 0.38 & - \\
\hline Artemisia annua & $\mathrm{AF}$ & - & - & 18.38 & 0.34 & 0.43 & 0.28 \\
\hline Artemisia anethifolia & $\mathrm{AF}$ & 1.46 & 0.04 & - & - & 0.01 & 0.02 \\
\hline Suaeda glauca & $\mathrm{AF}$ & 5.70 & 0.10 & - & 0.17 & 0.13 & 0.39 \\
\hline Suaeda hetroptera & $\mathrm{AF}$ & 0.34 & 99.26 & - & - & - & - \\
\hline
\end{tabular}

Note: PG, perennial grass; PF, perennial forb; AG, annual grass; AF, annual forb; -, not present. 
grazed meadow communities, species diversity and evenness were the lowest in $2006(P<0.05$, Figs. 2b and c).

\subsection{Vegetation cover, vegetation height and plant density}

In the fenced meadow, the vegetation cover and height showed significant increases from 2000 to 2005 and from 2005 to $2006(P<0.05)$, but slight increases from 2006 to 2008 (Table 1; Figs. 2a and b). They increased by $121.6 \%$ and $75 \%$ from 2000 to 2008, respectively. Plant density decreased significantly from 2000 to $2005(P<0.01)$, and then increased significantly from 2005 to 2006 in the fenced meadow $(P<0.01$; Table 1 ; Fig. 2c). In contrast, in the grazed meadow, vegetation cover and plant density decreased by $75.7 \%$ and 81.1\% from 2000 to 2008, respectively ( $P<0.01$; Table 1; Figs. 2a and c). In comparison to the grassland with continuous grazing, the fenced meadow had significantly higher vegetation cover and vegetation height in each sampling year ( $P<0.05$; Figs. $2 a$ and $b)$.

\subsection{Above- and belowground biomass}

In the fenced meadow communities, above- and belowground biomass increased significantly from 2000 to 2006 ( $P<0.05$; Table 1; Fig. 4), but there was not significant difference between 2006 and 2008 (Fig. 4). In the grazed meadow communities, from 2000 to 2008, above- and belowground biomass decreased by $80.6 \%$ and $83.7 \%$, respectively $(P<0.001$; Table 1 ; Fig. 4). In comparison to the grazed meadow communities, the fenced meadow communities had more above- and belowground biomass in each sampling year $(P<0.05$; Fig. 4).

\subsection{Soil physical and chemical properties}

In the fenced area, the soil $\mathrm{pH}, \mathrm{EC}$ and bulk density decreased gradually over time, while the soil $\mathrm{C}_{\text {org }}, \mathrm{N}_{\text {tot }}$, $\mathrm{P}_{\text {tot }}$ concentrations and carbon/nitrogen $(\mathrm{C} / \mathrm{N})$ ratio increased gradually. However, the reverse trend was found in the grazed area (Table 3). Soil bulk density was significantly lower in the fenced area compared with that in the grazed area during the three sampling
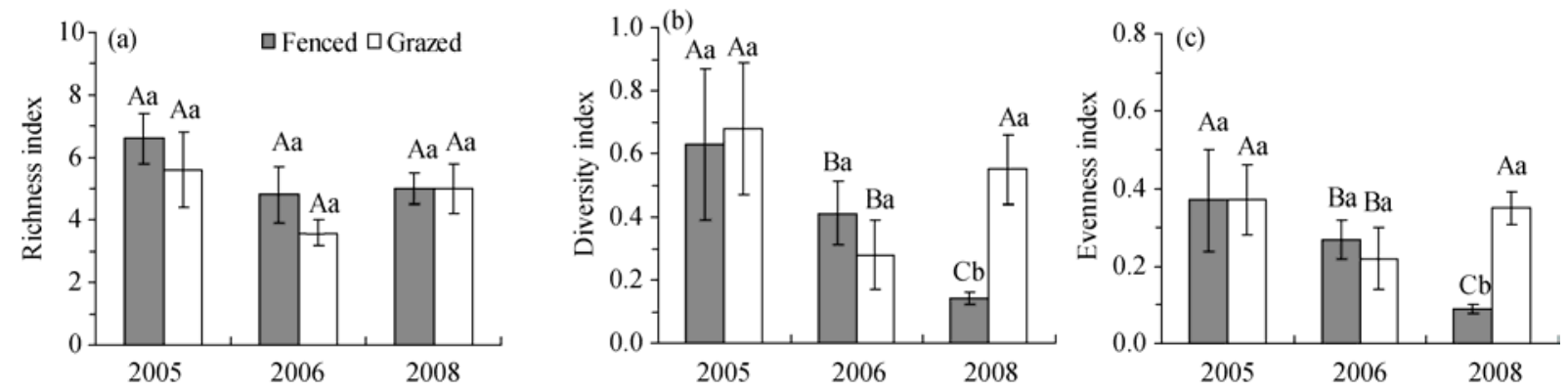

Fig. 2 Richness index (a), diversity index (b) and evenness index (c) in fenced meadow and grazed meadow in 2005,2006 and 2008. Values (mean \pm SE) are means of ten quadrats for each year. Means with different lowercase letters for each pair of bars indicate significant differences between treatments at $P<0.05$. Means with different uppercase letters across bars indicate significant differences between years within each treatment at $P<0.05$.
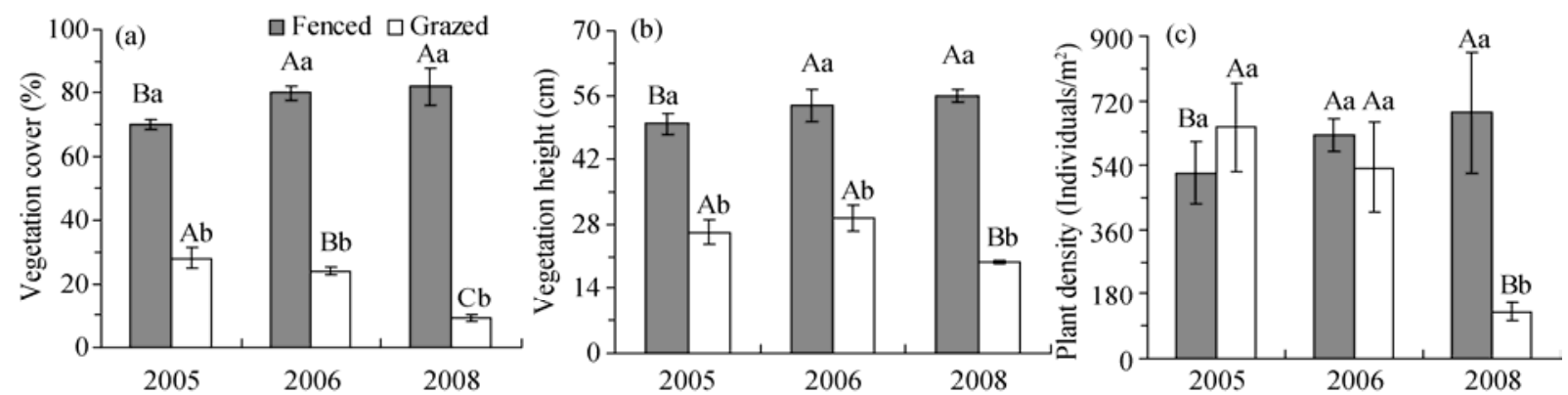

Fig. 3 Vegetation cover (a), vegetation height (b) and plant density (c) in fenced meadow and grazed meadow in 2005, 2006 and 2008. Values (mean $\pm S E$ ) are means of ten quadrats for each year. Means with different lowercase letters for each pair of bars indicate significant differences between treatments at $P<0.05$. Means with different uppercase letters across bars indicate significant differences between years within each treatment at $P<0.05$. 
years (Table 3). Similarly, both soil pH and EC were also significantly lower in the fenced meadow than in the grazed area, particularly in 2006 and 2008 (Table $3)$. In each sampling year, the fenced meadow had significantly higher soil $\mathrm{C}_{\text {org }}$ and $\mathrm{N}_{\text {tot }}$ concentration than the grazed meadow at the depth of $0-10 \mathrm{~cm}$ (Table 3). There was no significant difference in the soil $\mathrm{P}_{\text {tot }}$ concentration between fenced and grazed areas (Table 3).

Correlation analysis indicated that there were significant positive correlations between above-, and belowground biomass and soil $\mathrm{C}_{\text {org }}$ and $\mathrm{N}_{\text {tot }}$ concentration at the depth of $0-10 \mathrm{~cm}$ (Table 4), but negative correlations between above- and belowground biomass and pH, EC and soil bulk density (Table 4). No significant correlations were found for above- and belowground biomass and soil $\mathrm{P}_{\text {tot }}$ (Table 4).

\section{Discussion}

\subsection{Vegetation restoration under fencing}

Grazing management has variable effects on community structure in different grazed ecosystems (Guo, 2007; Marriott et al., 2009). Yayneshet et al. (2009) suggested that fencing a semi-arid, grass-wood mixed rangeland for more than 5 years increased species diversity in comparison to a grazed area of the rang-
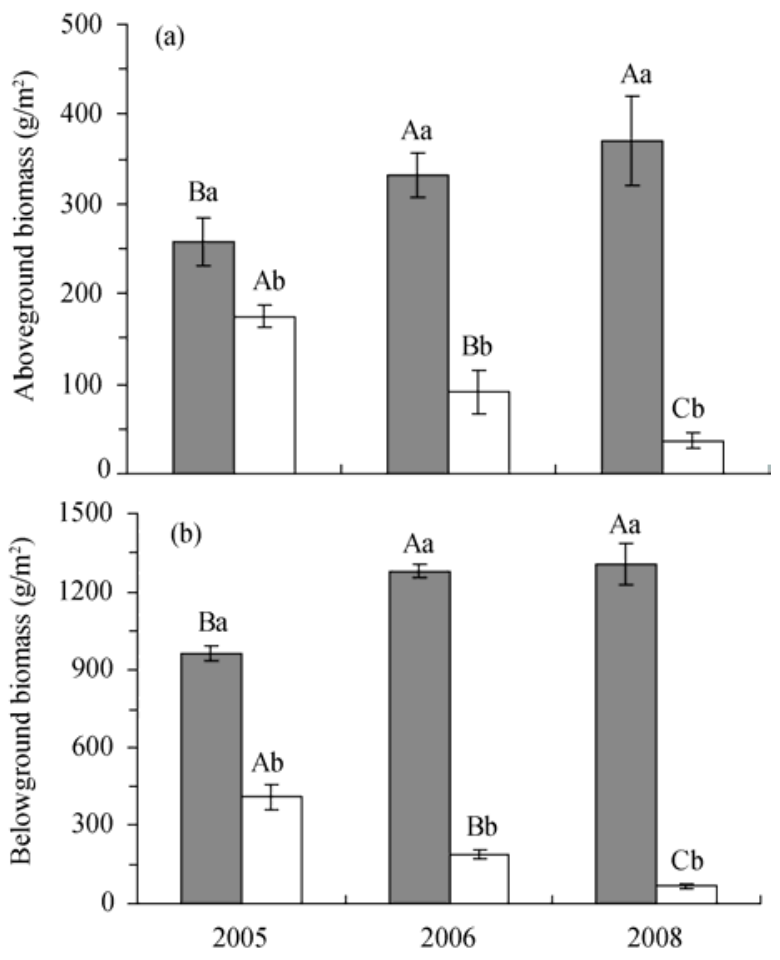

Fig. 4 Community aboveground (a) and belowground biomass (b) at 0-20 cm depth in fenced meadow and grazed meadow in 2005, 2006 and 2008. Values (mean \pm SE) are means of ten quadrats for each year. Means with different lowercase letters for each pair of bars indicate significant differences between treatments at $P<0.05$. Means with different uppercase letters across bars indicate significant differences between years within each treatment at $P<0.05$.

Table 3 Soil physical and chemical properties in fenced and grazed meadows

\begin{tabular}{|c|c|c|c|c|c|c|c|}
\hline \multirow[t]{2}{*}{ Soil property } & & \multicolumn{3}{|c|}{ Soil depth 0-10 cm } & \multicolumn{3}{|c|}{ Soil depth $10-20 \mathrm{~cm}$} \\
\hline & & 2005 & 2006 & 2008 & 2005 & 2006 & 2008 \\
\hline \multirow{2}{*}{$\mathrm{pH}$} & Fenced & $9.23 \pm 0.12^{\mathrm{A}}$ & $9.14 \pm 0.06^{\mathrm{ABb}}$ & $8.91 \pm 0.11^{\mathrm{Bb}}$ & $10.24 \pm 0.07^{\mathrm{A}}$ & $9.99 \pm 0.07^{\mathrm{Ab}}$ & $9.49 \pm 0.10^{\mathrm{Bb}}$ \\
\hline & Grazed & $9.48 \pm 0.07$ & $9.51 \pm 0.07^{\mathrm{a}}$ & $9.48 \pm 0.18^{\mathrm{a}}$ & $10.34 \pm 0.04$ & $10.32 \pm 0.08^{\mathrm{a}}$ & $10.38 \pm 0.14^{\mathrm{a}}$ \\
\hline \multirow{2}{*}{$\mathrm{EC}(\mu \mathrm{s} / \mathrm{cm})$} & Fenced & $430 \pm 20^{\mathrm{Ab}}$ & $385 \pm 13^{\mathrm{Ab}}$ & $238 \pm 11^{\mathrm{Bb}}$ & $1,045 \pm 23^{\mathrm{A}}$ & $839 \pm 70^{\mathrm{Bb}}$ & $772 \pm 23^{\mathrm{Bb}}$ \\
\hline & Grazed & $709 \pm 20^{\mathrm{Ba}}$ & $779 \pm 37^{\mathrm{ABa}}$ & $807 \pm 27^{\mathrm{Aa}}$ & $1,064 \pm 23$ & $1,062 \pm 25^{\mathrm{a}}$ & $1,133 \pm 62^{\mathrm{a}}$ \\
\hline \multirow{2}{*}{$\mathrm{C}_{\text {org }}(\mathrm{g} / \mathrm{kg})$} & Fenced & $6.92 \pm 0.22^{\mathrm{Ca}}$ & $7.96 \pm 0.13^{\mathrm{Ba}}$ & $9.45 \pm 0.36^{\mathrm{Aa}}$ & $6.00 \pm 0.27^{\mathrm{C}}$ & $6.88 \pm 0.10^{\mathrm{Ba}}$ & $7.56 \pm 0.33^{\mathrm{Aa}}$ \\
\hline & Grazed & $6.20 \pm 0.12^{\mathrm{Ab}}$ & $5.94 \pm 0.26^{\mathrm{ABb}}$ & $5.51 \pm 0.33^{\mathrm{Bb}}$ & $5.64 \pm 0.20^{\mathrm{A}}$ & $5.01 \pm 0.15^{\mathrm{Bb}}$ & $4.34 \pm 0.11^{\mathrm{Cb}}$ \\
\hline \multirow{2}{*}{$\mathrm{N}_{\text {tot }}(\mathrm{g} / \mathrm{kg})$} & Fenced & $0.82 \pm 0.01^{\mathrm{Ba}}$ & $0.86 \pm 0.02^{\mathrm{Aa}}$ & $0.90 \pm 0.02^{\mathrm{Aa}}$ & $0.75 \pm 0.01$ & $0.78 \pm 0.03^{\mathrm{a}}$ & $0.78 \pm 0.02^{\mathrm{a}}$ \\
\hline & Grazed & $0.77 \pm 0.01^{\mathrm{Ab}}$ & $0.76 \pm 0.02^{\mathrm{ABb}}$ & $0.72 \pm 0.01^{\mathrm{Bb}}$ & $0.70 \pm 0.01^{\mathrm{A}}$ & $0.64 \pm 0.02^{\mathrm{Ab}}$ & $0.56 \pm 0.02^{\mathrm{Bb}}$ \\
\hline \multirow{2}{*}{$\mathrm{C} / \mathrm{N}$} & Fenced & $8.44 \pm 0.25^{\mathrm{B}}$ & $9.28 \pm 0.34^{\mathrm{Ba}}$ & $10.50 \pm 0.45^{\mathrm{Aa}}$ & $8.01 \pm 0.36^{\mathrm{B}}$ & $8.90 \pm 0.49^{\mathrm{ABa}}$ & $9.77 \pm 0.47^{\mathrm{Aa}}$ \\
\hline & Grazed & $8.06 \pm 0.27$ & $7.82 \pm 0.39^{b}$ & $7.65 \pm 0.37^{\mathrm{b}}$ & $8.06 \pm 0.30$ & $7.82 \pm 0.48^{\mathrm{b}}$ & $7.75 \pm 0.49^{b}$ \\
\hline \multirow{2}{*}{$\mathrm{P}_{\text {tot }}(\mathrm{g} / \mathrm{kg})$} & Fenced & $0.21 \pm 0.02$ & $0.23 \pm 0.02$ & $0.25 \pm 0.02$ & $0.20 \pm 0.02$ & $0.22 \pm 0.01$ & $0.22 \pm 0.02$ \\
\hline & Grazed & $0.21 \pm 0.02$ & $0.20 \pm 0.02$ & $0.20 \pm 0.01$ & $0.19 \pm 0.02$ & $0.18 \pm 0.01$ & $0.18 \pm 0.01$ \\
\hline \multirow{2}{*}{$\mathrm{BD}\left(\mathrm{g} / \mathrm{cm}^{3}\right)$} & Fenced & $1.40 \pm 0.02^{\mathrm{b}}$ & $1.38 \pm 0.02^{\mathrm{b}}$ & $1.37 \pm 0.02^{\mathrm{b}}$ & $1.45 \pm 0.02^{\mathrm{b}}$ & $1.43 \pm 0.02^{\mathrm{b}}$ & $1.41 \pm 0.02^{\mathrm{b}}$ \\
\hline & Grazed & $1.58 \pm 0.04^{\mathrm{a}}$ & $1.59 \pm 0.04^{\mathrm{a}}$ & $1.60 \pm 0.03^{\mathrm{a}}$ & $1.63 \pm 0.03^{\mathrm{a}}$ & $1.64 \pm 0.02^{\mathrm{a}}$ & $1.64 \pm 0.02^{\mathrm{a}}$ \\
\hline
\end{tabular}

$\overline{\text { Note: Means with lowercase letters in a column indicate significant difference among treatments at } P<0.05 \text {; means with capital letters in a line indi- }}$ cate significant differences among years at $P<0.05$. 
Table 4 Pearson correlation coefficients between the aboveand belowground biomass $(0-10 \mathrm{~cm})$ and soil properties $(0-10$ $\mathrm{cm})$

\begin{tabular}{lcc}
\hline Soil property & Aboveground biomass & Belowground biomass \\
\hline $\mathrm{pH}$ & $-0.418^{*}$ & $-0.461^{*}$ \\
Electric conductivity & $-0.650^{* *}$ & $-0.675^{* *}$ \\
Soil organic carbon & $0.678^{* *}$ & $0.625^{* *}$ \\
Total nitrogen & $0.739^{* *}$ & $0.721^{* *}$ \\
Total phosphorus & 0.457 & 0.296 \\
Bulk density & $-0.748^{* *}$ & $-0.847^{* *}$ \\
\hline
\end{tabular}

Note: ${ }^{*}$ and ${ }^{* * *}$ indicate significance at $P<0.05$ and $P<0.01$ levels, respectively.

land. Wu et al. (2009) reported opposite findings from an alpine meadow, and their study showed that species richness and diversity were significantly lower in a fenced grassland than in a grazed grassland after 5 years of fencing. In our study, fencing did not induce any significant changes in meadow communities' species richness in comparison to grazed meadows. However, when protected from grazing by fencing, plant species composition, plant density and biomass were greatly changed in meadow communities. With fencing, plant density and biomass gradually increased for $L$. chinensis while declined for other species. Total plant density and aboveground biomass of $L$. chinensis increased by more than $72 \%$ in 2005, 5 years after fencing, and by more than 90\% in 2006 and 2008 compared to the conditions prior to fencing in 2000 (Table 2). As a result, by 2008 the plant diversity and evenness in the fenced area had decreased in comparison to the grazed meadow.

Leymus chinensis is a perennial, rhizomatous grass that can establish individuals via rhizomes and that has better survival adaptations than other plants. When grazing pressure increases, rhizome propagation is favored over sexual reproduction as a way of avoiding frequent aboveground disturbance (Wang, 2000). Although individual growth and sexual propagation are suppressed, the dependence on rhizome propagation can help the $L$. chinensis population avoid local extinction. When grazing is excluded, the remaining $L$. chinensis propagules can quickly stimulate population restoration. The quick restoration of $L$. chinensis populations may inhibit the development of other species by out-competing them for resources. Therefore, it is well known that the restoration of vegetation in this degraded meadow is primarily driven by release of suppressed L. chinensis individuals and not by recruitment of new species (Zhou et al., 2011).

Frequent, heavy grazing or overgrazing reduces the vegetation cover, plant height and biomass in grasslands, while excluding herbivores can be an effective way to restore vegetation (Pei et al., 2008; Wu et al., 2009; Liu et al., 2011). In our study, excluding grazing by fencing gradually increased ground cover and belowground biomass at the depth of $0-20 \mathrm{~cm}$ over time. In 2006, 6 years after fencing, the vegetation cover, plant height, above- and belowground biomass had reached $80 \%, 53.7 \mathrm{~cm}, 331.3 \mathrm{~g} / \mathrm{m}^{2}$ and $1,307.5$ $\mathrm{g} / \mathrm{m}^{2}$ respectively, which was no different from the pre-degraded status in 1983 (Table 1; Figs. 3 and 4). No further improvement was recorded, although the site received higher rainfall in the growing season (from April to September) in 2008 (240.3 mm, Fig. 1) than in 2006. We conclude that 6 years of grazing exclusion is an enough time to restore plant cover and productivity in degraded grassland that previously underwent 15 years of extensive grazing with a mean stocking rate of $8.5 \mathrm{DSE} / \mathrm{hm}^{2}$.

\subsection{Soil restoration under fencing}

Increased soil bulk density is an important indicator of degradation in grazed ecosystems, as it can further alter soil properties, such as water infiltration and retention, and thereby restrain plant growth (Salihi and Norton, 1987; Rubio and Bochet, 1998). Removal of grazers can decrease soil bulk density by excluding livestock trampling and restoring vegetation (Dakhah and Gifford, 1980; Su et al., 2004). These findings were also supported by our study, in which soil bulk density decreased in the fenced area and subsequently promoted vegetation establishment, while continuous grazing increased soil bulk density and suppressed vegetation establishment. There were significant, negative correlations between soil bulk density and above- and belowground biomass (Table 4).

Soil alkalinity is the principal restriction on vegetation establishment in this area (Gao et al., 1996). Soil $\mathrm{pH}$ and EC are two synergetic, key measurements to assess soil alkalinity. High soil $\mathrm{pH}$ and EC can restrain plant establishment and growth by increasing osmotic stress, ion toxicity and $\mathrm{pH}$ stress (Shi and Wang, 2005). In the current study, we found negative correlations between soil pH, EC and plant biomass (Table 4). Shi and Wang (2005) confirmed that increasing the soil 
$\mathrm{pH}$ to above 8.8 can decrease the survival rate, tillering rate, number of rhizomes and relative growth rate of $L$. chinensis. Our results show that soil $\mathrm{pH}$ decreased from 9.42 in 2000 to 8.91 in 2008 in the fenced area. Reduced $\mathrm{pH}$ provided more opportunities for the establishment of $L$. chinensis, the dominant species in this grassland, thus facilitating vegetation restoration. Restoration of vegetation can promote nutrient cycling via decomposition and decreased nutrient loss via runoff and wind erosion, owing to its protection of soil surface, which has a positive effect on increasing the soil $\mathrm{C}$ and $\mathrm{N}$ concentrations ( $\mathrm{Li}$ et al., 2009; Wu et al., 2010). Our results confirmed that the soil $\mathrm{C}_{\text {org }}, \mathrm{N}_{\text {tot }}$ concentration and above- and belowground biomass are strongly, positively correlated (Table 4).

In our research, although the soil $\mathrm{C}_{\text {org }}$ and $\mathrm{N}_{\text {tot }}$ synergistically increased with fencing and decreased under grazing, the soil $\mathrm{C} / \mathrm{N}$ ratio varied in different years (Table 3). The change in the soil $\mathrm{C} / \mathrm{N}$ ratio among years in this study indicates that grazing management affects soil $\mathrm{C}_{\text {org }}$ to a larger extent than $\mathrm{N}_{\text {tot }}$, similar to findings reported from a sandy grassland and a desert grassland in northern China (Su et al., 2005; Pei et al., 2008). The slight change in soil $P_{\text {tot }}$ concentration indicates that soil $\mathrm{P}_{\text {tot }}$ responds more slowly to changes in grazing management.

The improvement of soil properties during natural ecosystem restoration is a complicated and long-term process, particularly when they have deteriorated rapidly due to disturbances (Su et al., 2005). By our statistics, the soil $\mathrm{pH}$ at a depth of $0-10 \mathrm{~cm}$ in the fenced area did not change significantly from 1983 (pre-degradation) to 2008. The soil $\mathrm{C}_{\text {org }}, \mathrm{N}_{\text {tot }}$ and $\mathrm{P}_{\text {tot }}$ concentrations in the fenced area at $0-10 \mathrm{~cm}$ depth in 2008 were 1.47, 1.14 and 1.25 times higher than the values in 2000 (before fencing), respectively. These values in the fenced area were $0.86,0.91$ and 1.00 higher relative to the values in the grazed area, but they were still significantly lower than those in 1983 $(P<0.05$; Tables 1 and 3$)$. We established a best-fit equation by using a curve estimation regression to reflect the changes in soil $\mathrm{C}_{\text {org }}, \mathrm{N}_{\text {tot }}$ and $\mathrm{P}_{\text {tot }}$ concentrations at $0-10 \mathrm{~cm}$ depth following restoration time (year), and the three equations are as follows: $\mathrm{C}_{\text {org }}=6.174 \times \mathrm{e}^{0.044 \times \text { time }}, \mathrm{N}_{\text {tot }}=0.782 \times \mathrm{e}^{0.016 \times \text { time }}, \mathrm{P}_{\text {tot }}=0.196$ $\times \mathrm{e}^{0.026 \times \text { time }}$. If soil $\mathrm{C}_{\text {org }}, \mathrm{N}_{\text {tot }}$ and $\mathrm{P}_{\text {tot }}$ concentrations at
$0-10 \mathrm{~cm}$ depth continue to be restored at the same rate as they were from 2000 to 2008, then the restoration of soil $\mathrm{C}_{\text {org }}, \mathrm{N}_{\text {tot }}$ and $\mathrm{P}_{\text {tot }}$ concentration would need 16, 30 and 19 years, respectively, to attain their 1983 levels. Therefore, the complete restoration of soil chemical properties from degraded soil via fencing is a far longer process than 8 years and may take twice as long to accomplish as the degradation time. Certainly, a change in climate and disturbance may accelerate or retard it, and these factors need further research.

\subsection{Implications for grassland management}

Our results indicate that exclusion of grazers by fences can have a positive effect on restoring vegetation and soil properties in this degraded alkaline grassland. The vegetation in this degraded meadow was primarily restored by the release of suppressed $L$. chinensis individuals, which emphasizes the importance of remaining $L$. chinensis individuals as a precursor to vegetation restoration. Therefore, the $L$. chinensis population should be monitored closely as a criterion for managing and assessing the restoration potential of this degraded grassland.

The restoration processes for vegetation and soil were different in this degraded grassland. To restore the vegetation after overgrazing took less than half of the time than what was needed for the restoration of soil $\mathrm{N}$. Therefore, it is recommended that stocking rate should be reduced to $1 / 3$ of the current carry capacity, or a grazing regime of 1 year of grazing followed by a 2-year rest period should be adopted to sustain the current status of vegetation and soil resources. However, if $\mathrm{N}$ fertilizer is applied, the rest period of the degraded meadow could be shortened, with the duration of the rest depending on the rate of $\mathrm{N}$ application.

\section{Conclusions}

By examining changes in the vegetation characteristics and soil properties following fencing and grazing in this degraded alkaline grassland, we confirm that fencing can effectively increase the vegetation cover and forage production, reduce soil bulk density and $\mathrm{pH}$, and improve soil nutrient properties in comparison to continuous grazing. However, the restoration of soil properties was a longer and more complicated process than vegetation recovery, and thus may need more time and investment. For example, 6 years of 
grazing exclusion was enough to restore vegetation, but the restoration of soil $\mathrm{C}_{\text {org }}, \mathrm{N}_{\text {tot }}$ and $\mathrm{P}_{\text {tot }}$ concentrations may need 16, 30 and 19 years, respectively, in a degraded alkaline grassland that had undergone 15 years of extensive grazing with a mean stocking rate of $8.5 \mathrm{DSE} / \mathrm{hm}^{2}$. The current study also emphasizes the importance of conserving the $L$. chinensis population, as the restoration of vegetation in this degraded meadow was primarily accomplished through the release at suppressed $L$. chinensis individuals, but not through recruitment of new species.

\section{Acknowledgements}

This study was supported by the National Key Basic Research Program of China (2011CB403203) and the Strategic Science and Technology Guide Project of Chinese Academy of Sciences (XDA05050401). We thank Kelly HOPPING for her support in English language revision.

\section{References}

Bauer A, Cole C V, Black A L. 1987. Soil property compares on in virgin grasslands between grazed and nongrazed management systems. Soil Science Society America Journal, 51(1): 176-182.

Daily G C. 1995 . Restoring value to the worlds degraded lands. Science, 26(5222): 350-354.

Dakhah M, Gifford G F. 1980. Influence of vegetation, rock cover and trampling on infiltration rates and sediment production. Journal of the American Water Resources Association, 16(6): 979-986.

Dormaar J F, Adams B W, Willms W D. 1994. Effects of grazing and abandoned cultivation on a Stipa-Bouteloua community. Journal Rangeland Management, 47(1): 28-32.

Fleischner T L. 1994. Ecological costs of livestock grazing in western North America. Conservation Biology, 8(3): 629-644.

Gao Q, Yang X S, Yun R, et al. 1996. MAGE, a dynamic model of alkaline grassland ecosystems with variable soil characteristics. Ecological Modelling, 93(1): 19-32.

Gonzales E K, Clements D R. 2010. Plant community biomass shifts in response to mowing and fencing in invaded oak meadows with Non-Native grasses and abundant ungulates. Restoration Ecology, 18(5): 753-761.

Guo Q F. 2007. The diversity-biomass-productivity relationships in grassland management and restoration. Basic and Applied Ecology, 8(3): 199-208.

Hofstede R G M. 1995. The effects of grazing and burning on soil and plant nutrient concentrations in Colombia Páramo grasslands. Plant and Soil, 173(1): 111-132.

Holmgren M, Scheffer M. 2001. El Niño as a window of opportunity for the restoration of degraded arid ecosystems. Ecosystems, 4(2): 151-159.

Institute of Soil Science, Chinese Academy of Sciences (ISSCAS). 1978 Physical and Chemical Analysis Methods of Soils. Shanghai:
Shanghai Science Technology Press, 87-102.

Jiang S C, He N P, Wu L, et al. 2010. Vegetation restoration of secondary bare saline-alkali patches in the Songnen plain, China. Applied Vegetation Science, 13(1): 47-55.

Klute A. 1986. Methods of Soil Analysis. Part 1-Physical Mineralogical Methods. Madison, WI: American Society of Agronomy, INC, 363-375.

Lavado R S, Sierra J O, Hashimoto P N. 1996. Impact of grazing on soil nutrients in a Pampean grassland. Journal of Range Management, 49(5): 452-457.

Li F R, Zhao W Z, Liu J L, et al. 2009. Degraded vegetation and wind erosion influence soil carbon, nitrogen and phosphorus accumulation in sandy grasslands. Plant and Soil, 317(1-2): 79-92.

Liu Y S, Pan Q M, Liu H D, et al. 2011. Plant responses following grazing removal at different stocking rates in an Inner Mongolia grassland ecosystem. Plant and Soil, 340(1-2): 199-213.

Mainguet M. 1994. Desertification: Natural Background and Human Mismanagement. Heidelberg: Speringer-Verlag, 306.

Manzano M G, Návar J. 2000. Processes of desertification by goats overgrazing in the Tamaulipan-thrnscrub (matorral) in north-eastern Mexico. Journal of Arid Environments, 44(1): 1-17.

Marriott C A, Hood K, Fisher J M, et al. 2009. Long-term impacts of extensive grazing and abandonment on the species composition, richness, diversity and productivity of agricultural grassland. Agriculture, Ecosystem and Environment, 134(3): 190-200.

Page A L. 1982. Methods of Soil Analysis. Part 2-Chemical and microbiological properties. Madison, WI: American Society of Agronomy, INC, 539-579.

Pei S F, Fu H, Wan C G. 2008. Changes in soil properties and vegetation following exclosure and grazing in degraded Alxa desert steppe of Inner Mongolia, China. Agriculture, Ecosystem and Environment, 124(1): 33-39.

Peterson G, Allen C R, Holling C S. 1998. Ecological resilience, biodiversity, and scale. Ecosystems, 1(1): 6-18.

Pywell R F, Bullock J M, Hopkinsi A, et al. 2002. Restoration of species-rich grassland on arable land: assessing the limiting processes using a multi-site experiment. Journal of Applied Ecology, 39(2): 294-309.

Rubio R W, Bochet E.1998. Desertification indicators as diagnosis criteria for desertification risk assessment in Europe. Journal of Arid Environment, 39(2): 113-120.

Ruiz-Jaen M C, Aide T M. 2005. Restoration success: how is it being measured? Restoration Ecology, 13(3): 569-577.

Salihi D O, Norton B E. 1987. Survival of perennial grass seedling under intensive grazing in semiarid rangelands. Journal of Applied Ecology, 24(1): 145-151.

Schlesinger W H, Reynolds J F, Cunningham G L, et al. 1990. Biological feedbacks in global desertification. Science, 247(4946): 1043-1048.

Shang Z H, Deng B, Ding L M, et al. 2013.The effects of three years of fencing enclosure on soil seed banks and the relationship with above-ground vegetation of degraded alpine grasslands of the Tibetan plateau. Plant and Soil, 364(1-2): 229-244.

Shi D C, Wang D L. 2005. Effects of various salt-alkaline mixed stresses on Aneurolepidium chinense (Trin.) Kitag. Plant and Soil, 271(1-2): 15-26. 
Silver W L, Kueppers L M, Lugo A E, et al. 2004. Carbon sequestration and plant community dynamics following reforestation of tropical pasture. Ecological Applications, 14(4): 1115-1127.

Snyman H A. 2003. Revegetation of bare patches in a semi-arid rangeland of South Africa: an evaluation of various techniques. Journal of Arid Environment, 55(3): 417-432.

Sparks D L, Page A L, Helmke P A, et al. 1996. Methods of Soil Analysis. Part 3-Chemical Methods. Madison, WI: American Society of Agronomy, INC, 1085-1121.

Su Y Z, Zhao H L, Zhang T H, et al. 2004. Soil properties following cultivation and non-grazing of a semi-arid sandy grassland in northern China. Soil and Tillage Research, 75(1): 27-36.

Su Y Z, Li Y L, Cui J Y, et al. 2005. Influences of continuous grazing and livestock exclusion on soil properties in a degraded sandy grassland, Inner Mongolia, northern China. Catena, 59(3): 267- 278.

Suding K N, Gross K L, Houseman G R. 2004. Alternative states and positive feedbacks in restoration ecology. Trends in Ecology and Evolution, 19(1): 46-53.

Taylor Jr C A, Garza Jr N E, Brooks T D. 1993. Grazing systems on the Edwards Plateau of Taxas: are they worth the trouble? Rangelands, 15(2): 53-57.

van der Merwe J P A, Kellner K. 1999. Soil disturbance and increase in species diversity during rehabilitation of degraded arid rangelands. Journal of Arid Environments, 41(3): 323-333.

Wang H, Li X, Long H, et al. 2007. Monitoring grassland degradation in Yiminhe Mine of China using TM remotely sensed data. Geoscience and Remote Sensing Symposium, 2007. IGARSS 2007. IEEE In- ternational, 3441-3443.

Wang R Z. 2000. Effect of grazing on reproduction in Leymus chinensis population. Chinese Journal Applied Ecology, 11(3): 399-402.

Wang Y, Zhao H L, Zhao X Y. 2013. Effects of land use intensity on the restoration capacity of sandy land vegetation and soil moisture in fenced sandy land in desert area. Contemporary Problems of Ecology, 6(1): 128-136.

Wu G L, Du G Z, Liu Z H, et al. 2009. Effect of fencing and grazing on a Kobresia-dominated meadow in the Qinghai-Tibetan Plateau. Plant and Soil, 319(1-2): 115-126.

Wu G L, Liu Z H, Zhang L, et al. 2010. Long-term fencing improved soil properties and soil organic carbon storage in an alpine swamp meadow of western China. Plant and Soil, 332(1-2): 331-337.

Yayneshet T, Eik L O, Moe S R. 2009. The effects of exclosures in restoring degraded semi-arid vegetation in communal grazing lands in northern Ethiopia. Journal of Arid Environments, 73(4): 542-549.

Zhang W Z. 1994. The relationship between vegetation degeneration and soil salinization in an Aneurolepidium chinense grassland of Songnen plain. Acta Phytoecologica Sinica, 18(1): 50-55.

Zhao W Z, Xiao H L, Liu Z M, et al. 2005. Soil degradation and restoration as affected by land use change in the semiarid Bashang area, northern China. Catena, 59(2): 173-186.

Zhou D W, Li Q, Song Y T, et al. 2011. Salinization-alkalization of Leymus chinensis grassland in Songnen Plain of Northeast China. Chinese Journal Applied Ecology, 22(6): 1423-1430. 